\title{
Biology of Begonia sect. Wageneria (Klotzsch) A.DC. under cultivation conditions (ex situ)
}

\author{
Tatiana Fershalova*, and Elena Baikova \\ Central Siberian Botanical Garden SB RAS), 630090 Novosibirsk, Russia
}

\begin{abstract}
Morphological structure, features of growth and development of Begonia species of the Wageneria section (B. convolvulacea, B. glabra, $B$. fagifolia) under ex situ conditions were studied. The architectural model and structure of inflorescences, as well as the dynamics of shoot growth and flowering, are established and described. Recommendations for the optimal cultivation of the Wageneria section begonias in greenhouses and rooms are presented. The main factor affecting the success of cultivation and decorative effect is the air temperature; the optimal one is $+20-30{ }^{\circ} \mathrm{C}$. Begonia convolvulacea and B. glabra proved to be the most resistant to various cultivation conditions.
\end{abstract}

\section{Introduction}

Begonia is a mega-genus with about 2500 species [1]. In 1954, Klotzsch described the Wageneria section, which included 16 species [2]. Until recently, it was believed that this section has 7 species [3]. Currently, the section contains 6 species, since $B$. smilacina A.DC. has been recognized as a synonym of B. glabra Aubl. [4]. Three species of the Wageneria section are cultivated in the CSBG SB RAS collection: $B$. convolvulacea (Klotzsch) A.DC., B. glabra, and B. fagifolia Fisch. ex Otto. The description of B. glabra was first published in 1775 by Jean Baptiste Aublet [5]. B. convolvulacea was first discovered by the German naturalist Frederick Sello in 1853 and the following year introduced to the Schönbrunn gardens in Vienna [6]. The plant was described in 1854 under the basionym Wageneria convolvulacea by Johann Friedrich Klotzsch [2]. The botanical description of $B$. convolvulacea was first given by Alphonse de Candole in Flora Brasiliensis, 1861 [7]. In 1936, German botanists Christoph Otto and David Dietrich published a description of B. fagifolia [8].

The main characteristics of the Wageneria section are as follows: plants lianescent, anthers dehiscent with laterally positioned, longitudinal slits; styles free, placenta per locule; seed with a "crown" (micropylar or chalazal end inflated) [9].

The begonias of the Wageneria section are native to South and Central America. B. glabra has the widest range, from Mexico to Brazil, B. convolvulacea found throughout Brazil. B. fagifolia has a more limited range. It is found in Brazil, growing only in in the coastal Atlantic forest, southeast and northeast (Rio de Janeiro, in the north of Espirito Santo and in the south of Bahia) [10].

* Corresponding author: fershalova@yahoo.com 
In the Atlantic forest Begonia species occupy different biotypes, such as marshes, sunlight places and wet soil, rain and dry forests, altitude vegetation and xerophytes vegetation [11, 12]. B. convolvulacea, B. glabra, and B. fagifolia prefer to grow as epiphytes or hemiepiphytes and are usually found in trees, in shaded and light places. They can sometimes be seen on rocky cliffs [10]. B. glabra grows not only on trees, but also along the edges of paths [13].

All of these begonias are widely used in landscaping in America and Europe [6]. In Siberia, these species are still rare; most often they are found in private collections. In order to promote the wider cultivation of these species, a more detailed study of their biological characteristics is necessary. Thus, the study of the morphological structure, and features of the growth and development of species ex situ became the goal of our study. The results obtained allowed to develop recommendations for optimal cultivation begonias of the Wageneria section.

\section{Material and methods}

The studies were carried out in the Central Siberian Botanical Garden of the Siberian Branch of the Russian Academy of Sciences (CSBG SB RAS, Novosibirsk, Russia) over 20 growing seasons (2000-2021). Plant samples are obtained from the V.L. Komarov Botanical Institute of the Russian Academy of Sciences, Saint Petersburg ( $B$. convolvulacea, 1980; B. fagifolia, 2000) and from the N.V. Tsitsin Main Botanical Garden of the Russian Academy of Sciences, Moscow (B. glabra, 1999).

The climate of Novosibirsk is continental; its essential feature is the rapid heating of the air in the spring and its intence cooling in autumn. The average onthly daytime air temperature in August is $+16^{\circ} \mathrm{C}$, the minimum is $+10^{\circ} \mathrm{C}$. In September, the values of these indicators decrease, respectively, to $+10^{\circ} \mathrm{C}$ and $+2^{\circ} \mathrm{C}$ [14]. At subzero air tempetatures during the cold period, begonias can be grown indoors.

We studied Begonia plants in various conditions: in greenhouses (tropical and subtropical) and interiors (office rooms). In the greenhouse with a tropical climate, plants were grown at a temperature of $+20-35^{\circ} \mathrm{C}$, humidity 50-90 \%, illumination 2000-5000 Lx. In a greenhouse with a subtropical climate, the air temperature during the year varied from +5 to $35^{\circ} \mathrm{C}$, air humidity was $30-70 \%$, illumination $1000-5000 \mathrm{Lx}$. Some plants were taken outdoors after the average daily air temperature was set at $+10^{\circ} \mathrm{C}$ (second decade of May) and returned back in the greenhouse after the leaves had completely died off (second half of August).

To assess the adaptive capabilities and prospects of cultivation of the Wageneria section begonias, we recorded the main indicators, such as: morphological traits and types of shoot growth, seasonal rhythms of plant growth and flowering, completeness of ontogenesis, the ability of plants to vegetative and seed reproduction $[15,16]$. The decorative properties of plants were also evaluated.

\section{Results}

The most significant structural feature of begonias shoot system is the continuous monopodial growth of the axes and the axillary position of the inflorescences. In begonias of the Wageneria section all vegetative shoots are plagiotropic. So, all the studied species belong to the monopodial plagiotropic long-metameric architectural model [17]. Vegetative shoots of the studied begonias are uniformly leafy along the entire length, creeping along the surface of the soil and rooting in the nodes, with a raised tip (Fig. 1 a). They can be 
attached to a support (wood, stones, artificial pillars and grates) with the help of adventitious roots and creep on the surface of the soil without support.

The length of begonia shoots cultivated ex situ is limited to 2-3 meters by the space of the greenhouse (Table 1). When grown in pots, plant growth is limited by the size of the pots. The length of the shoots in nature varies, reaching, for example, $15 \mathrm{~m}$ in B. glabra.

Table 1. Main characteristics of begonias of the Wageneria section

\begin{tabular}{|c|c|c|c|c|}
\hline & \multirow{2}{*}{ Place } & \multicolumn{3}{|c|}{ Begonia species } \\
\hline & & B. convolvulacea & B. glabra & B. fagifolia \\
\hline \multirow{4}{*}{ Flowering period, month } & Nature $^{1}$ & $\begin{array}{c}\text { V-IX* } \\
\text { I-III, V, VI-X** }\end{array}$ & $\mathrm{I}-\mathrm{XII} * *$ & VII-IX* \\
\hline & $\mathrm{I}^{2}$ & I-III, V, VII, IX & $\mathrm{I}-\mathrm{X}$ & V-VII \\
\hline & II & IV-V, VII-VIII & II-IX & VI \\
\hline & III & II, V, VI, VIII & I-IX & VI \\
\hline \multirow{4}{*}{ Length of the peduncle, $\mathrm{cm}$} & Nature & $\begin{array}{c}14-56^{*} \\
6,8-53,8^{* *}\end{array}$ & $\begin{array}{c}17-22 * \\
13,5-35 * *\end{array}$ & $\begin{array}{c}20-27 * \\
20-70 * *\end{array}$ \\
\hline & I & $6-10$ & $5-7$ & $3-4 *, 3-5 * *$ \\
\hline & II & $3-8$ & $2-5$ & $1-2$ \\
\hline & III & $5-10$ & $3-4$ & $1-3$ \\
\hline \multirow{4}{*}{$\begin{array}{l}\text { Number of flowers per one } \\
\text { inflorescence, pcs. }\end{array}$} & Nature & $70-200 * *$ & $50-100 * *$ & - \\
\hline & I & $50-150$ & $40-90$ & $200-250$ \\
\hline & II & $30-60$ & $30-60$ & $150-200$ \\
\hline & III & $30-70$ & $30-70$ & $150-180$ \\
\hline \multirow{4}{*}{ Length of the main shoot, $\mathrm{m}$} & Nature & $2-8 * *$ & $3-7 *, 2-15^{* *}$ & $3-4 *, 3-5 * *$ \\
\hline & I & $2-3$ & $2-3$ & $2-3$ \\
\hline & II & $1,5-2$ & $1,5-2$ & $1-2$ \\
\hline & III & $1,5-2$ & $1,5-2$ & $0,5-1$ \\
\hline \multirow{4}{*}{ Length of internodes, $\mathrm{cm}$} & Nature & $3,5-18^{*}, 3-17^{* *}$ & $2,2-7,5 *$ & $2^{*}, 4-4,7 * *$ \\
\hline & I & $5-7$ & $4-5$ & $1-2$ \\
\hline & II & $5-6$ & $3-4$ & $1-2$ \\
\hline & III & $5-6$ & $2-4$ & $0,5-1$ \\
\hline \multirow[t]{3}{*}{ Size of the sheet blade, $\mathrm{cm}$} & Nature & $\begin{array}{l}6-11 \times 7-25,5^{*} \\
5,5-25 \times 9-29 * * \\
\end{array}$ & $\begin{array}{c}7,5-10,5 \times 5,5-7 * \\
5-18 \times 2,5-13^{* *} \\
\end{array}$ & $\begin{array}{l}7-11,2 \times 2-4,5^{*} \\
7-8 \times 5,6-6,8^{* *}\end{array}$ \\
\hline & I & $6-10 \times 9-12$ & $4-11 \times 2,5-7$ & $5-6 \times 2,5-6$ \\
\hline & II & $3,5-5 \times 8-10$ & $6-8 \times 2-9$ & $3-6 \times 2-4$ \\
\hline
\end{tabular}




\begin{tabular}{|c|c|c|c|c|}
\hline & III & $4,5-6 \times 8-11$ & $3-9 \times 2-7$ & $3-6 \times 2-5$ \\
\hline \multirow{3}{*}{ Length of the petiole, cm } & Nature & $\begin{array}{c}2,8-18^{*} \\
3,7-29,5^{* *}\end{array}$ & $\begin{array}{c}1,2-2,5^{*} \\
1,1-9^{* *}\end{array}$ & $\begin{array}{c}1,1-3^{*} \\
1,7-2^{* *}\end{array}$ \\
\cline { 2 - 5 } & I & $5-7$ & $2-5$ & $1-1,5$ \\
\cline { 2 - 5 } & II & $1-3$ & $1-4$ & $1-1,2$ \\
\cline { 2 - 5 } & III & $1-3$ & $1-3$ & $1-1,3$ \\
\hline
\end{tabular}

${ }^{1}$ According to the literature data: Kollmann, 2012 [10]*; Gregório 2016 [13]**

${ }^{2}$ Ex situ growing conditions: I - tropical greenhouses, II - subtropical greenhouses, III - rooms

The begonias of the Wageneria section cultivated in tropical greenhouse do not have a distinct dormant period. In February, begonias begin intensive growth, but its rate varies in different species: the fastest growth of shoots is observed in B. glabra. In April, the growth of shoots slows down (Fig. 2). The growth dynamics in B. convolvulacea and especially in $B$. fagifolia is smoother, so they these species can be attributed to the group of constantly growing plants. When cultivating begonias in interiors, such growth patterns are preserved. In greenhouse with a subtropical climate, the growth of begonias slows down when the temperature drops to $+5-10^{\circ} \mathrm{C}$ in winter. Shoots with short internodes are formed at this tima. The shortest internodes, $0.5 \mathrm{~cm}$ long, are formed in B. fagifolia (Table 1).

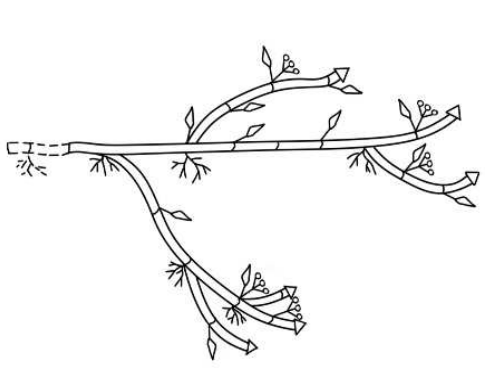

a

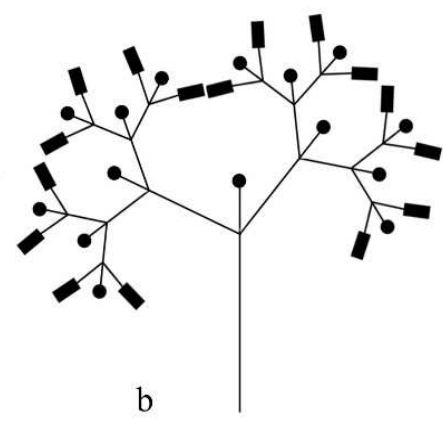

$\mathrm{b}$

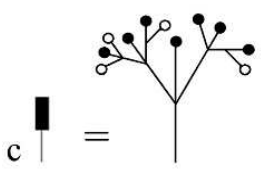

Fig. 1. Structure of the shoot systems in Begonia section Wageneria: monopodial plagiotropic longmetameric architectural model (a); scheme of dichasial inflorescence (b) with its terminal part (c).

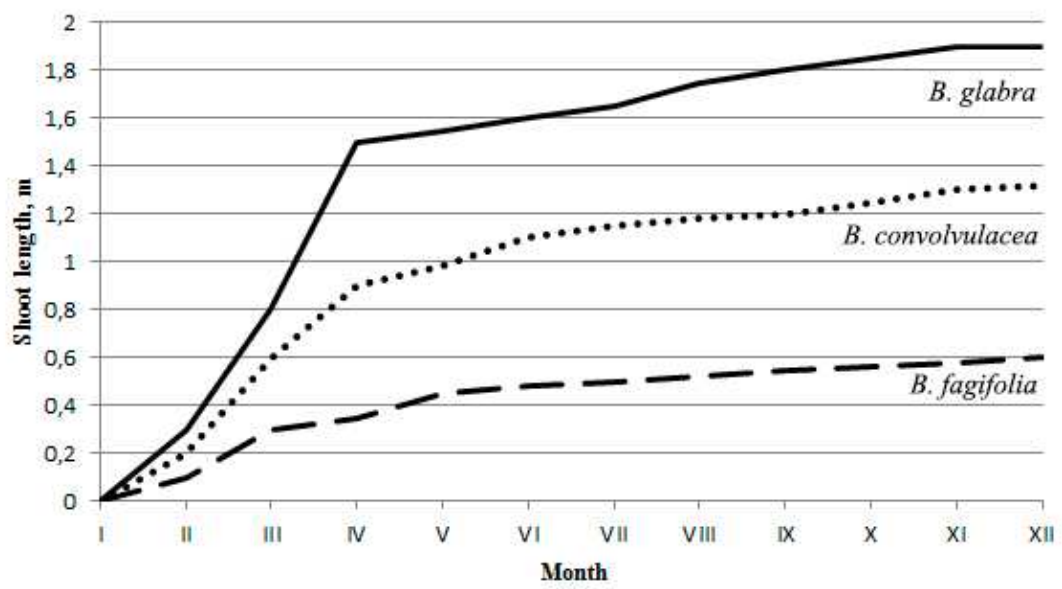

Fig. 2. Dynamics of the shoot growth in Begonia species cultivated in a tropical greenhouse. 
The leaf blades of the studied begonia species differ significantly, both in shape (Fig. 3) and size. The latter depends on the growing conditions: at low temperatures (less than $+10^{\circ} \mathrm{C}$ ) and insufficient humidity (less than $20 \%$ ), smaller leaves are formed (Table 1). In B. fagifolia, unlike other species, the leaves are covered with long hairs. The shape and color of the leaves, as well as the texture of the surface are significant indicators of the decorative appearance of the species.

All the studied species bloom cultivated ex situ. Inflorescences of Begonia are axillary, dichasial, with bracts and not reduced axes, bisexual, with male flowers basal and female flowers distal, protandrous [9, 18]. In begonias of the Wageneria section, dichasia are multi-tiered (Fig. $1 \mathrm{~b}$ ), branching up to the 6-8th order, with a slight depletion of the branching of the higher orders, so terminal cyma may be monochasial (Fig. $1 \mathrm{c}$ ). The peduncles are arranged vertically; their height varies greatly and depends on the growing conditions (Table 1). The height of inflorescences ex situ is $2-7 \mathrm{~cm}$ in B. glabra, 3-10 cm in B. convolvulacea, and $1-3 \mathrm{~cm}$ in B. fagifolia. In nature, according to L.J.C. Kollmann [10] and B.S. Gregório [13], inflorescences can reach a large size, for example, up to $56 \mathrm{~cm}$ in $B$. convolvulacea (Table 1). The flowers are white, small, with petals 1-4 mm long; in begonias growing in nature, the petals can be to $7 \mathrm{~mm}$ (B. fagifolia). The number of flowers per inflorescence varies from 20 to 250 pcs., both in nature and in cultivation (Table 1). Due to the protandrous blooming, male and female flowers can be simultaneously in the same inflorescence only for a short time.

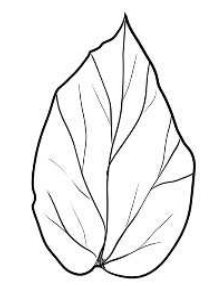

a

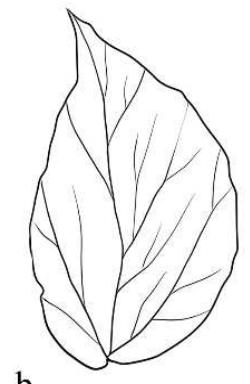

$\mathrm{b}$

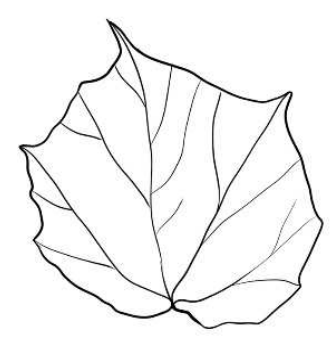

$\mathrm{c}$

Fig. 3. Typical leaf blade shape of Begonia, section Wageneria: B. fagifolia (a), B. glabra (b), B. convolvulacea $(\mathrm{c})$.

The duration and time of flowering differ in begonia species (Table 1). B. glabra does not have a pronounced flowering cessation from January to October under optimal growing conditions but the intensity of flowering varies during this period. B. convolvulacea blooms from January to October periodically: from January to March, and then in May, July, and September. B. fagifolia has the shortest flowering period which is from May to July. The intensity of flowering of all species decreases when the air temperature drops to $+15^{\circ} \mathrm{C}$. Flowering stop completely at $+10^{\circ} \mathrm{C}$.

Begonias of the Wageneria section are thermophilic plants. Their growth processes slow down when the air temperature drops to $+10^{\circ} \mathrm{C}$, and the leaves turn yellow at $+5^{\circ} \mathrm{C}$.

A drop in temperature below zero provokes the fall of all leaves and flowers. Therefore, these plants can be grown outdoors in Siberia only in summer. Pots with begonias are taken out of the greenhouse after the threat of frost has passed, that is, in the third decade of May. And they need to be brought back to the greenhouse in the third decade of August, when there is a chance of night frosts. 


\section{Discussion}

Regular flowering, fruiting, and the formation of full-fledged seeds in begonias of the Wageneria section outside their natural range indicate their high adaptive potential. $B$. convolvulacea and $B$. glabra proved to be the most resistant to various cultivation conditions. B. fagifolia is more difficult adapting to deviations from the optimal growing regime. The main factor affecting the success of cultivation and the decorative effect is the temperature. The optimal temperature for growing begonias of the Wageneria section is $+20-30^{\circ} \mathrm{C}$. With a decrease in temperature, the growth of shoots is inhibited, shorter peduncles and smaller leaves are formed, the number of inforescences and flowers decreases.

We recommend the studied species of begonias for growing indoors as groundcover and climbing plants. They usually have a lot of side shoots, so they are great for hanging in baskets or for making poles and trellises. Their decorative effect is mainly due to the dense rich green foliage. Research shows that people experience an unconscious calming response when looking at green foliage [19], also touching the surface of the leaves [20]. If you follow the necessary agrotechnical measures, you can achieve abundant flowering of these begonias in spring and summer.

In the conditions of Siberia, we recommend begonias of the Wageneria section for growing not only in greenhouses and winter gardens, but also in the rooms of various functional purposes. It was found that the volatile biologically active substances produced by $B$. convolvulacea reduce the microbial contamination of indoor air [21], so we recommended this species for the creation of phytomodules in kindergartens and schools. B. convolvulacea and B. glabra are suited for outdoor cultivation in hanging baskets which are placed in the garden from June to August, when there is no threat of frost.

The work was carried out within the framework of the State Assignment of Central Siberian Botanical Garden SB RAS. When preparing the publication, the materials of bioresource scientific collection of CSBG SB RAS «Collections of living plants indoors and outdoors», USU 440534 were used.

\section{References}

1. D-K. Tian, Y. Xiao, Y-Ci. Li, K-J. Yan, PhytoKeys, 153 (2020)

2. J. F. Klotzsch, Begoniaceae - Gattungen und Arten (Kön. Preuss. Akad. Wiss., Berlin, 1854)

3. P. W. Moonlight, W. H. Ardi., L. A. Padilla, et al., Taxon 67 (2) (2018)

4. E. L. Jacques, B. S. Gregório, Begoniaceae in Flora do Brasil (Jardim Botânico do Rio de Janeiro, 2020)

5. J. B. C. F. Aublet, Histoire des plantes de la Guiane Françoise, 2 (P.F. Didot jeune, Londres-Paris, 1775)

6. M. C. Tebbitt, Begonias: Cultivation, Identification, and Natural History (Timber Press, Portland, 2005)

7. C. F. P. von Martius, A. G. Eichler, I. Urban, Flora Brasiliensis, Vol. 4(1) (Missouri Botanical Gardens, 1861)

8. C. F. Otto, A. G. Dietrich, Allg. Gartenzeitung 4, (1836)

9. J. Doorenbos, M. S. M. Sosef, J. J. F. E. de Wilde, Agric. Univ. Wagen. Pap. 98, 2 (1998)

10. L. J. C. Kollmann, Diversidade, Biogeografia e Conservação das Begoniaceae do Estado do Espírito Santo, Brasil (Ceunes, São Mateus 2012) 
11. L. J. C. Kollmann, A. P. A. Fontana, Rodriguésia 59, 4 (2008)

12. M.C. Ribeiro, A. C. Martensen, J. P. Metzger, et al., The Brazilian Atlantic Forest: A Shrinking Biodiversity Hotspot, in Biodiversity Hotspots (Springer-Verlag, Berlin, Heidelberg, 2011)

13. B. S. Gregório, J. A. S. Costa, A. Rapini, Sitientibus série Ciências Biológicas 16 (2016)

14. I. O. Luchitskaya, N. I. Belaya, S. A. Arbuzov, Climate of Novosibirsk and its changes (Publishing House SB RAS, Novosibirsk, 2014)

15. T. D. Fershalova, E. V. Baikova, Introduction of Begonia in greenhouses and interiors (GEO, Novosibirsk, 2013)

16. E. V. Baikova, T. D. Fershalova, E. A. Karpova, et al., The flora of Asian Russia 4 (2016)

17. E. V. Baikova, T. D. Fershalova, Botan. J. 92, 8 (2007)

18. E.V. Baikova, T.D. Fershalova, Botan. J. 94, 10 (2009)

19. B. Grinde, G. G. Patil, Int. J. Environ. Res. Public Health 6 (2009)

20. K. Koga, Y. Iwasaki, Journal of Physiological Anthropology 32, 7 (2013)

21. N. V. Tsybulya, T. D. Fersalova, Samara Journal of Science 10, 1 (2021) 